\title{
From the Desk of Editor-in-Chief
}

\author{
Sinha Ramesh ${ }^{1}$
}

Published online: 2 March 2022

(C) Indian Council of Philosophical Research 2022

The writings collected together with this issue of JICPR intend to be representatives of the mainstream Philosophy of today. The urge for today in philosophy is to go back to our traditions and roots of philosophical thoughts. Attempts have been made to include articles which have been properly reviewed by eminent experts. The Chief Editor is nevertheless aware that philosophy is a serious subject. But there is honest agreement regarding what is to count as classic and what is to be counted as contemporary. In Indian thought we find continuity of philosophical thought. As a matter of fact, classic and contemporary are not set apart. I confess that editing the Journal of philosophical research is quite difficult. We don't find experts of the subjects available to review the articles because some of the scholars are not computer friendly due to advanced age. Some hardly take pains to read the manuscripts written by others. But there are quite a good number of young scholars who do hard work. Some of the articles could not be included because they do not belong to the discipline of philosophy. The articles selected have been restricted to philosophy or sister disciplines.

In the present volume of JICPR, Prof. Kanchan Saxena in her article "Ethical foundation of Perpetual Peace" adheres that ethics is the foundation of perpetual peace. According to Kant, perpetual peace is an ideal. The paper "To die or not to die: A Kantian Perspective on Euthanasia" attempts to explore the implications of Kant's moral criticism of suicide in the case of euthanasia. In all cases of euthanasia, death should be caused for the welfare of the patient. In the article, "Time and Some Temporal Notions: A Vaiśesika Analysis", Maitryee Datta has tried to state realist Philosophers understanding of time. The article entitled "Sri Aurobindo's Philosophy of Nationalism and its contemporary Relevance" attempts to streamline the concept of Nation. Dr. Sudhir singh has worked out the growth of Nationalism in the light of Sri Aurobindo's philosophy. Dr. Surya Kant Maharana has tried to give a comparative account on the Notion of Self in Buddha and Wittgenstein.

I wish to thank all the contributors. I am also thankful to reviewers who have meticulously done the job. This is to mention that Sri Vikram Kumar assisted to complete the editing work. Hope this issue will serve the needs of students, research scholars and teachers of philosophy and other allied subjects.

Sinha Ramesh

rcsinha22@gmail.com

1 Patna, India 
Publisher's Note Springer Nature remains neutral with regard to jurisdictional claims in published maps and institutional affiliations. 